\title{
Autistic architecture: the fall of the icon and the rise of the serial object of architecture
}

\section{Maria Kaika}

School of Environment and Development, The University of Manchester, Manchester M13 9PL, England; e-mail: maria.kaika@manchester.ac.uk

Received 7 September 2010; in revised form 28 January 2011

\begin{abstract}
In this contribution I sketch a framework for interpreting the parallel process of banalisation of old and proliferation of new 'iconic' corporate architecture as the Janus-faced manifestation of a qualitative shift in the relationship between capital and architecture. Highlighting the change from place-bound, place-loyal urban elites to footloose transnational elites, I argue that after the 1970s the need to develop a new set of building specifications and use values to accommodate the requirements of a new urban economy was matched by an equally pressing need to institute a new set of symbolic values for a new generation of elites. Drawing upon Castoriadis's work, I conceptualise architecture as the narrativisation of the desires of elites during a given era, and as a key component in instituting a society's radical imaginary during moments of change. Within this framework, I argue that despite their common commitment to spectacular design, there are a number of significant differences between contemporary and earlier corporate 'icons'. Discerning the distinct symbolic, material, and social role of contemporary corporate buildings, I challenge their identification as 'iconic' architecture and place them instead under a new category, which I term 'autistic architecture'.
\end{abstract}

"Each new situation requires a new architecture."

Jean Nouvel (2005)

\section{Architecture as narrativisation of desire}

"This building ... [will] be a monument to my life ... the last skyscraper ever built in New York ... the greatest ... the last achievement of man on earth ... a statement of my life. After I am gone that building will be Gail Wynand. I've waited for it from the day I was born."

Ayn Rand (1947, pages 579-580)

The above excerpt from The Fountainhead, Ayn Rand's influential 1947 novel, recounts a fictional conversation between Gail Wynand, a powerful New York media tycoon and Howard Roark, a talented young architect. Homage to modernist architecture and manifesto of enlightened architectural patronage, The Fountainhead depicts an almost erotic relationship between architecture and private capital. The 'monument to his life' that Mr Wynand asks the architect to design is what most self-respecting early-20thcentury urban tycoons with enough capital and a sense of place-loyalty aspired to commission. Although Mr Wynand is a figment of Rand's imagination, his words echo those with which Hilla Rebay, art advisor to Solomon R Guggenheim, wooed Frank Lloyd Wright into designing the New York Guggenheim Museum in $1943^{(1)}$. She stated that her client wanted nothing less than a 'temple of spirit' and 'a monument'. Indeed, while European skylines were still dominated by buildings erected in the name of civil society (museums, churches, town halls, etc), ${ }^{(2)}$ late-19th-century and

(1) Completed in 1959 .

(2) See, for example, the Turun Sanomat Building in Turku, Finland, headquarters to the homonymous newspaper, founded as the mouthpiece for the liberal Young Finnish Party (designed by A Aalto, 1927-1929); Aarhus Town Hall, (designed by A Jacobsen, 1937); Centennial Hall, Breslau, Poland (designed by M Berg, 1912); Exhibition Hall in Turin (designed by P L Nervi, 1949); Finnish Pavillion in Paris, France (designed by A Aalto, 1935-1937); Halsingborg Concert Hall 
early-20th-century American capital pioneered the skyscraper as one of the first iconic building types erected in the name of private capital. The Chanin Building; ${ }^{(3)}$ the Rockefeller Center; ${ }^{(4)}$ the Seagram Building; ${ }^{(5)}$ the Woolworth Building, later known as the 'Cathedral of Commerce'; ${ }^{(6)}$ and the Trump Building, the 'Crown Jewel of Wall Street', (7) all carried the names of their patrons and were erected in homage to their lives and achievements. Clad in luxurious material and conspicuously displaying wealth and power, these buildings were elevated by the public imagery to the status of urban icons soon after their erection (Twombly, 1996) and became sought-after business locations. Headquarters in the Empire State, the Chanin, or the Seagram Building signified 'cultural capital', kudos, and a sense of achievement for any corporation that would occupy them (Abalos et al, 2003; Fainstein, 1994; Sklair, 2006).

However, from the 1970s onwards, these buildings lost much of their allure as desirable business locations. One after the other, many of the once-cherished locations in Manhattan and the emblematic sites in the City of London were abandoned or rejected by corporations in favour of new, often nondescript, headquarter buildings (Jacobs, 1994; Kaika, 2010; Kynaston, 2005; Sennett, 2001). In less than half a century, across the Western world, corporate elites went from funding and building urban icons to refusing to occupy them. Corporate buildings that were once made to last forever and to be on a par with the great monuments of humankind became obsolete. However, while these earlier icons are shunned or redeveloped, a new generation of impressively designed corporate buildings sprout across the globe: amongst many others, London's Swiss Re Headquarters, ${ }^{\left({ }^{8}\right.}$ Birmingham's Selfridges, ${ }^{(9)}$ Munich's BMW Welt, ${ }^{(10)}$ Beijing's China Central Television Tower (CCTV), ${ }^{(1)}$ Kuala Lumpur's Petronas Twin Towers, ${ }^{(12)}$ Dubai's Porsche Design Towers, ${ }^{(13)}$ Abu Dhabi's Ferrari World, ${ }^{(14)}$ etc. The new corporate commissions receive wide media attention, and have become the object of academic enquiry in architecture, geography, sociology, and urban studies (Alexander, 2008; Bouzarovski, 2009; Domosh, 1990; Jacobs, 1994; 2006; MacKeith, 2005; McNeill, 2002; 2005; 2005b, 2006; Sennett, 2001; Sklair, 2001; 2005; 2006; Zukin, 1988,1991 ; 1995). However, as intellectual inquiry focuses on contemporary commissions, an analysis that links the banalisation of the old and the proliferation of new corporate 'icons'(15) is still to be undertaken, and the question that Gottman (1966)

(2) (continued)

in Halsingborg, Sweden (designed by S Markelius, 1932); Karl Marx Hof in Vienna, Austria (designed by K Ehn, 1930); National Pensions Building in Helsinki, Finland (designed by A Aalto, 1952); Police Headquarters in Copenhagen, Denmark (designed by H Kampmann, 1918 - 1924); Stockholm Library in Stockholm, Sweden (designed by E G Asplund, 1918 - 1927).

(3) Designed by Sloan and Robertson, 1929, as a tribute to the life of Irwin S Chanin, New York developer and entertainment tycoon.

(4) Designed by Harrison and Hood, 1939.

(5) Designed by Van der Rohe and Johnson, 1958, headquarters to Canadian distillers J E Seagram and Sons.

(6) Designed by Cass and Guilbert, 1913.

(7) Designed by Severance, Matsui, and Shreve and Lamb, 1930.

(8) Commissioned 2000, Norman Foster.

(9) Commissioned 2001, Amanda Levete and Jan Kaplicky (Future Systems) Architects.

(10) Commissioned 2007, to Coop Himmelb(1)au.

(11) Commissioned 2002, to Rem Koolhaas.

(12) Completed 1998. Designed by César Pelli and Djay Cerico.

(13) Commissioned 2007, OMA and Porsche Design Studios.

(14) Scheduled for completion 2010. Benoi architects.

(15) As the paper puts under scrutiny the 'iconic' status of contemporary corporate commissions, I use 'iconic' in inverted commas when referring to contemporary commissions throughout the paper. 
posed back in 1966 - ie, whether, as the skyscraper spreads around the world, it still carries the same meaning and function as it did in the beginning-remains unanswered and becomes today more relevant than ever.

In this contribution I sketch an interpretative framework for unpacking the parallel process of, on the one hand, the 'banalisation' of early-20th-century corporate icons, and, on the other hand, the proliferation of a new generation of 'iconic' architecture. London and New York in particular (though not exclusively) are the laboratories upon which I draw to exemplify the theoretical points in this paper. By focusing on the 'banalisation' of old and the proliferation of new corporate 'icons', my intention is to examine this parallel process as the Janus-faced manifestation of a qualitative shift in the relationship between urban elites and architectural patronage and to argue that this change requires further attention and systematic analysis. Highlighting the recent shift from place-bound, place-loyal urban elites to footloose transnational elites, I argue that after the 1970s the need to develop a new set of building specifications and use values to accommodate the requirements of the new urban economy is matched by an equally pressing need to develop a new set of symbolic values, a new radical imaginary for a new generation of transnational elites.

Building on Castoriadis's work (Castoriadis, 1987; Castoriadis and Curtis, 1997a; 1997b) on the Imaginary Institution of Society, I depict iconic architecture as an urban totem, ie not only a means of expressing/signifying existing elite power, but also as one of the most effective means for instituting new elite power, and constituting new social relations as real or naturalised during moments of social, economic, or political change. Seen through this interpretative framework, both the rejection of old corporate icons and the frantic race across the world to build the next ones are linked to the need to institute a new 'radical urban imaginary' for a new generation of elite power. I argue that earlier corporate icons are rejected not because they do not fulfil the need for provision of up-to-date infrastructure specifications or 'flexible' workspaces, but mainly on the grounds that they still allude to a now transcended relationship between private capital and the city.

Drawing a comparison between early-20th-century and contemporary corporate 'icons', I explain that although these buildings share a commitment to impressive design and a desire to dominate the urban skyline they nevertheless are distinct in significant ways - notably their symbolic role, the ways in which they relate to the city that surrounds them, their relationship to time/ruination, their production process, as well as the ways in which they become scripted into the public imagery.

I conclude by arguing that the new symbolic and material role, the distinct social characteristics, as well as the new rituals of 'iconification' that accompany the commission of contemporary corporate buildings, demand a reconceptualisation of these commissions - one that removes them from the category of 'iconic' objects and puts them closer to what Baudrilliard (1996) terms 'serial' objects, and into a category to which I refer as 'autistic architecture'. The emergence of autistic architecture across the world, I argue, has profound effects on the production and use of urban space.

\section{Iconic architecture as totem}

"The ruin is a way to dominate history continuously."

Speer (1970, page 76)

Architectural icons hold a special place in history as exemplifiers of the aspirations and values of societies and as embodiments of myths and wish images for the future. The Egyptian Pyramids, the Athenian Parthenon, the European Medieval Cathedral, and the American Skyscraper still exude immense power as signifiers that define distinct historical moments and as embodiments of the desires and ambitions of 
particular social organisations and their elites (Koepnick, 2001). Like the name and the insignia of a nation, a tribe, or a country; like the symbols and rituals of a religion; like the rules and institutions of a community, iconic architectural objects have functioned across history as totems of a particular social order, as part of a system of significations that define the collectivity of a society across time, beyond its "perishable molecules" and "provide each society with answers to fundamental questions of origin, identity, purpose, relation to other societies, etc" (Castoriadis, 1987, page 147).

Castoriadis terms this system of imaginary significations that plays a key role in organising human behaviour and social relations the actual imaginary (figure 1). His definition of the actual imaginary and its importance in maintaining social order and regulating human behaviour is close to Lacan's concept of the symbolic order, and to Freud's analysis of the symbolic as "the pact which links ... subjects together in one action" (Miller, 1991, page 230). However, in his Imaginary Institution of Society, Castoriadis offers a more radical reading of semiotics, which goes beyond establishing a link between language and power. This reading asserts that history not only exists in and through language; it also gives itself this language, it constitutes and transforms this language according to its needs (Castoriadis, 1987, page 138). The system of significations that each society institutes is not important only for organising or reproducing its collective identity and ritual; it is also responsible for producing the collective identity of this society as a real and existing entity. In short, a society is not just defined by its symbols; it also produces the symbols it needs in order to perpetuate itself through time. Symbols provide not only the necessary means for a collective identity to express itself; they also provide the means for this collective identity actually to exist in the first place, to come into being as a collective. "The social-historical sets up ... a universe of significations ... to which it owes its unity and coherence, the specific structure of its elements, a certain understanding of the external natural world and its relation to the society ... a certain definition of the 'real' social needs, which the functionality of the institutions must serve" (Kavoulakos, 2006, page 203).

Castoriadis consolidates the fundamental distinction between symbols that perpetuate the identity of a social order, and symbols that institute the identity of a social order in the concept of the radical imaginary. The radical imaginary is "the elementary and irreducible capacity of evoking images" and constitutes the "origin of the symbolic" (Castoriadis, 1987, page 127). Whilst the actual imaginary is the ability of a

The ability of a society to produce images and symbols to express an already constituted collected identity.

Actual imaginary

Radical imaginary

Essential in organising human behaviour and social relations.

(Castoriadis, 1987, pages 146-147)

The ability of a society to institute new images and symbols for something that does not actually exist yet; something that is still in the making.

(Castoriadis, 1987, footnote 25, page 388, see also pages $146-147$ )

Essential for any collective identity to transcend the field of the 'potential' and enter the field of the 'actually existent'.

(Castoriadis, 1987, pages 147-160)

Figure 1. Actual and radical imaginary. 
society to express an already constituted collective identity, the radical imaginary is the ability of a collective to institute a new universe of significations (Castoriadis, 1987, page 146), a new set of images and symbols for something that does not actually exist yet, but is still in the making (figure 1).

Take, for example, the case of nationalism. The nation-state was constituted as a real existing entity through the institution of a new radical imaginary: the symbols for state-nationalism (flag, anthem, maps, common language, etc) acted not as representations of a homogeneous nation already existing within specific borders but as part and parcel of constituting this nation as an actually existing 'thing', as a performative entity. Private property is another example of a constituted historically geographically specific imaginary signification that was instituted as real through a radical imagination of symbols and institutions, and it marked "a new way for society to live, to see itself and to conduct itself as articulated in an antagonistic and asymmetrical manner, a signification that [was] immediately symbolized and sanctioned by rules" (Castoriadis, 1987, page 154). Although this system of significations is a mystification, nevertheless, its imaginary institution has real material effects. For example, although nationalism is a mystification, its imaginary institution has "effects so massively and terribly real that it proves itself to be much stronger than any 'real' forces", stronger even than the human instinct of self preservation when a call to 'die for one's county' comes to the fore (Castoriadis, 1987, page 148). Similarly, the fact that slavery was the imaginary institution of a particular historical era does not do away with the terrible and very real material effects that slavery and the slave trade had on the economies of societies and on the livelihoods of human beings. The system of imaginary significations, the language that each society or collectivity institutes for itself, is what subsequently posits this society or collectivity as an existing substance that "grows heavier and materializes" with time (Castoriadis, 1987, page 148). In short, the radical imaginary is essential for any collective identity to transcend the field of the 'potential' and enter the field of the 'actually existent' (Castoriadis, 1987; see also Kavoulakos, 2006).

The distinction between actual imaginary and radical imaginary, offers a powerful analytical framework that enables us to go beyond establishing the link between signifier and signified, and beyond the well-documented link between ideology, power, and symbolism. It opens up an avenue to explore the reasons why a collective identity (eg, a nation, a society, an institution) needs symbolic expressions in the form of language, music, art, or architecture, to institute and assert itself in the first place (Kaika, 2010, page 457). As it enables us to explore discontinuity, this framework institutes a foundation for theorising change, "the alteration of significations, [and] the break with tradition" (Kavoulakos, 1996, page 202). If collectives not only define themselves through language but also constitute and transform their language according to their needs at any historical moment (Castoriadis, 1987, page 138), then the need for a new radical imaginary becomes imperative during moments of change, as it provides the symbols that will act both as signifiers of the new order, and as means of constituting this new order as real and 'natural'.

Seen within this framework, the language of architecture is more than just the signifier and the narrativisation of the instituted power of a corporation, a state, a church, or a city. It is also a means of constituting this symbolic authority as real, a means of teaching society what to desire and how to desire it (Žižek, 1989). This logic goes beyond asserting architecture as central for sustaining the socio-political fantasy of each historical epoch; it also depicts architecture as a totem, a performative entity for constituting new authority or new social relations as real or naturalised. Particularly during moments of significant social, economic, or political change, iconic objects of architecture operate as part of a new radical imaginary, and perform a 
double role: that of signifiers of power, but also that of constituting a new language, new symbols and myths for a new configuration of power, for a society in search of a new identity; for cities, corporations, states, nations, and religious authorities in need of rebranding.

\section{Instituting the myth of modernity: the rise and fall of the modernist corporate icon}

Acknowledging the imperative for a secular modern society to institute itself though a new set of symbols and myths, Dadaist and Surrealist pioneer Louis Aragon offered a new mythology of modernity, in which iconic architecture features as a key protagonist. His Paris Peasant (1994 [1926]) is an ode to iconic technological constructions and infrastructure networks. To Aragon these structures are more awesome and powerful than any deity of the ancient world. The importance of architecture in constructing and sustaining the myth of a modern society is also present in his Mirror-wardrobe One Fine Evening (1924). In this poetic depiction of the modern city, architectural objects feature as mythical entities, guardians of the dialectic between light and shadow, thresholds between the old world and a new modern urban society (Read, 2005). Architecture as a key performative act in instituting a modern capitalist society also features centrally in Ayn Rand's work. The high priestess of capitalism and 'objectivism', and one of the most controversial cultural icons of early-20th-century America, Rand produced a systematic symbolic narrative for her ideal capitalist world order through novels, philosophical musings, media publications, and televised interviews. In her work she places architecture on the pedestal as the central totem of the world order she advocates, and architects on the podium as the high priests of a new social ethics. Her masterpiece The Fountainhead is an ode to the importance of architecture in instituting her ideal modern capitalist society. In the novel she makes a ruthless industrialist, $\mathrm{Mr}$ Wynand, state that there is no proper function for money, other than to become "the financial fertilizer that will make [the construction of iconic corporate buildings] possible" (Rand, 1947, page 613). Although this statement could easily be dismissed as hyperbolic, Rand's fictitious character was actually drafted closely in the image of early-20th-century New York tycoons, who spent lavishly in a fierce competition to produce the next tallest, most exuberant building that would project their power onto urban space and declare their commitment to the city that sustained and promoted their wealth.

The American corporate skyscraper is arguably the most paradigmatic modern manifestation of the role of architecture as part of the radical imaginary of a changing society. Being one of the first unashamedly iconic building types not related to civic society functions (Kaika and Thielen, 2006), the corporate skyscraper became a dramatic assertion of the shift of the symbolic order from state and church power to money and corporate power; it became a radically new totem in the service of a radically new secularised Western world. The great icons of early-20th-century American capitalism - the Rockefeller Center, the Chanin Building, the Empire State Building - were designed to stand on a par with the great architectural monuments of humankind and did more than just project their patrons' powerful image onto the urban skyline. They became a tool for narrating to the world the modern (American) myth for social emancipation through progress, design, technological innovation, and corporate power; they cast the myth of economic stability and power of American capital in stone, marble, and steel (MacKeith, 2005; Twombly, 1996). If Henry Ford's innovations 'democratised' the dream of car ownership, and turned the automobile from an item of luxury to an everyday object, the American skyscraper 'democratised' the dream of quality office building. These private architectural icons par excellence claimed to bring the democratising qualities of modernist design to the 
everyday lives of workers and city dwellers. In a public display of commitment to the urban community these buildings' luxuriant decorations and artwork were not confined only to the tycoons' private offices; employees, too, could feel 'at home' in their offices and could share the aesthetic delights that the Fordist new deal brought to them, alongside job security and welfare benefits. F L Wright's Johnson Wax Building in Racine, Wisconsin, "was all about ennobling the worker, giving the clerical workers the nave of the cathedral .... Even today, 70 years on, the visitor will find legions of secretaries typing away at desks Wright designed, basking in the subtle light, all of them fortunate enough ... to experience Wright's singular genius every time they come to work" (Paul Goldberger cited in Anon, 1998, page 1). Commenting on the same building, architect Philip Johnson also notes that F L Wright "gave the company's clerical workers one of the greatest public spaces in America. ... He built a palace, he built a church. He built something that just soared. It's the finest room, maybe, in the United States" (Burns, 1998, page 310). Similarly, the Rockefeller Center (principal architect Raymond Hood) featured public art in its lobbies and generous provision of open spaces that blended the private and the public in one continuous flow. AT\&T palace, a lavish 1.35 million square foot office building at Basking Ridge, New Jersey, designed by Vincent G Kling and Associates, also objectified Fordism's new aesthetic deal through offices with wood-burning fireplaces and an impressive entrance lobby that included a waterfall. Although these buildings were built as monuments to the glory of private capital, their provision of luxury office space for employees, their lavish lobbies and public spaces, and their claims to educating civil society to modernist aesthetics through cultural practices, put them squarely in the centre of the public imaginary, and turned them into icons that inspired a sense of civic and even national pride (MacKeith, 2005; Twombly, 1996).

It was this role of architecture as the radical imaginary of a society in the making, this role in narrating and sustaining the myth of capitalist progress, that elevated architecture and planning during the first half of the 20th century into social engineering and promoted what (Tafuri, 1999 [1973]) termed the "central illusion of architectural ideology": ie, the belief that a single design project can make a difference in the production of urban space and can ameliorate urban society. This myth of architecture as an instrument for social change, combined with the fidelity to a modernist emancipatory project, gave Adolf Loos the confidence to demand the sacrifice of ornament on the altar of a better society (Loos, 1998), Le Corbusier the self-righteousness to promote his Unités d'Habitation across the world as the best possible way of living, and Robert Moses the nerve to state: "I'm just going to keep on building. You do the best you can to stop it" (quoted in Berman, 1983, page 290). These bold statements resonate of an era that asserted the architect's role in producing a better future society as equally significant to the role of the politician or the industrialist.

However, after the 1970s the once mythical and sought-after business icons that were produced as part of the new social deal became banalised. Sennett (2001) reports how one of New York's jewels, the Chanin Building, was rejected in the 1980s as a possible location for the headquarters of an unnamed transnational corporation. A similar fate awaited the AT\&T office building, which closed down in the early 2000 s in favour of new offices at Bedminster, Bridgewater, and Morristown. Kynaston (2005) chronicles how, during the 1980s and 1990s, the Corporation of London struggled to persuade its banking and media institutions, as well as business consultants and lawyers, to remain loyal to their traditional locations in the City of London (BBC News, 2003; Jacobs, 1994). MacKeith (2005) offers a compelling analysis of how in 2003 the Helsinki Telephone Company (HPY) abandoned its impressive 'granite 
castle' in the city centre in favour of a new, nondescript headquarters building at the city's outskirts.

Indeed, after the 1970s the relation between architecture and corporate patronage changed dramatically. Along with the eclipse of the 'traditional' economic activities in Western cities, the 'traditional' species of the place-loyal urban tycoon that would tie his personal fortune with that of the city (and would get involved in the production of urban space and the reproduction of urban life) was also eclipsed. The almost mythic figures of Guggenheim, Rockefeller, Chanin, Carnegie, Mellon, Ford, Pirelli, and Agnelli, were replaced by a new generation of urban elites, who are as distinct from their predecessors as the economy they produce is from the early-20th-century economy. The new urban elites tend not to associate themselves with any specific city or locale, and have no particular interest in urban social and political life. According to Sennett, "they want to operate in a city but not rule it; they compose a regime of power without responsibility" (2007, no page). Sklair terms this new generation of footloose transnational elites 'the Transnational Capitalist Class' and argues that they are "more or less in control of the process of globalization" and are "beginning to act as a transnational dominant class" (2001, pages 5-6).

The footloose character of new urban elites and their lack of place loyalty and commitment inevitably affect the relationship between capital and urban space. Borrowing the term from Marcel Proust, Sennett describes this new generation of elites as the city's 'passive beloved'; like a lover who constantly threatens to leave, and by doing so, makes one offer perks and gifts to make them stay, contemporary transnational corporations are ready, at any moment, to leave the city in which they presently have their headquarters. By doing so, they make city councils, city officials, and the state offer them 'gifts' in the form of amenities, subsidies, tax breaks, etc, in order to convince them to remain loyal (Sennett, 2001). Peter Wynne Rees, The City Planning Officer for the City of London, confirms:

"We don't have a great deal of difficulty to attract [transnational corporations to the City of London]. But it would be very easy for us to frighten them away if we weren't doing the right thing ... if we weren't going to have [new] high rise buildings or if we didn't have late night bars in the City or whatever it might be. ... Then they might have said oh we'll go somewhere else" (interview, 2007).

As stability and continuity (the once great virtues of capitalist urban development) have become character defects, the new generation of urban elites finds unpalatable the place loyalty expressed in earlier corporate commissions. Indeed, although the lack of spatial amenities - in the form of flexibility, increased ceiling heights, enhanced daylight, and better IT infrastructure - are often quoted by essayists, analysts, and architectural critics as key reasons behind the rejection of once iconic corporate buildings (Booth, 2001; Finch, 1992), corporations themselves cite instead the loyalty of these earlier corporate palaces to place, and their commitment to that old Fordist pact between employer and employee, as their most unsavoury and undesirable features. The resolution of earlier corporate iconic architecture to make workers feel at home, and to make lobbies and plazas integral parts of the urban public realm, have no place in contemporary corporate culture and practice. The Chanin Building was rejected due to the fact that it was "too beautiful" and on account of anxiety, on the part of employers, that workers might become too attached to the building, and even "feel they belong there" (Sennett, 2001, no page). Following a similar narrative, as AT\&T was leaving its palatial headquarters, the company's spokesman, Gary Morgenstern, asserted that "we would never build a headquarters of such magnificence today" (Antoinette, 2001, no page). Geoff Schubert, managing director with CB Richard Ellis, also declared in reference to AT\&T's iconic building that "very few companies will take 
a building like this today" (Antoinette, 2001, no page). As part of the same corporate culture that shuns old-style corporate palaces lest workers feel they belong to their workplace, many of the corporations that hold offices today in the Lloyd's building in London, do not allocate personal desk space to their employees. Instead, employees are only allowed to 'book' a desk for a few hours in the building (mainly when they wish to impress an important client) and are expected to retreat afterwards to their open-plan desks in nondescript office buildings in London's suburbs (interview, George, City employee, 2009).

In short, the commitment to employees that used to be a main asset for earlier corporate icons has now become a crucial deficiency. The continuity, stability, job security, and place-loyalty symbolised by these buildings were part of the actual imaginary of an era that is long gone. These buildings are rejected today mainly because they represent a relationship between capital and architecture, between employers and employees, that is now forsaken. Having been part of the actual imaginary of a social formation that changed radically after the 1970s, these buildings cannot narrate the new myth of flexible accumulation and footloose corporate existence. The new corporate existence calls instead for a new language, a new type of architecture, which not only facilitates a noncommittal relationship between employer and employee, but also acts performatively as the totem for instituting a new, noncommittal, relationship between capital and place. This, I argue, is a key role for the new generation of corporate 'icons', which are being commissioned in unprecedented numbers across the world over the last twenty years.

\section{Autistic architecture: the rise of the serial object of architecture autism $n$.}

A pathological self-absorption and preoccupation with the self to the exclusion of the outside world.

\section{(Dictionary of Psychology in Politics and Social Sciences)}

The corporate buildings commissioned over the last twenty years, designed by star architects, receiving wide media attention, and being canonised as 'emblematic' or 'iconic' even before they are erected (Ethington and Schwartz, 2006), appear, at first glance, to defy the material operational needs of contemporary corporations. If the architectural form that best fits the footloose, noncommittal existence of contemporary businesses is flexible, nondescript spaces that can be easily reconfigured to accommodate the ever-changing requirements of their tenants (Ada Louise Huxtable, cited in Sennett, 2001, no page), then the proliferation of the new generation of corporate 'iconic' buildings would be difficult - if not impossible - to explain only through an analysis of the new economy's different operational requirements. A standard cost - benefit economic analysis could not explain the proliferation of new corporate 'icons' either, since these buildings also defy advice offered by business gurus, who urge corporations to forego commissioning elaborate headquarters, as "setting commitments in stone ... can lock a company into a community ... and [can] signal permanence and continuity that may inhibit managers' ability to rethink and reverse their former commitments" (Sull, 2003, cited in MacKeith, 2005, page 58). Instead, I shall argue, the proliferation of this new generation of corporate 'iconic' commissions has to be interpreted as part of the process of instituting a new system of imaginary significations, a new radical imaginary for a new economy.

As part of this new radical imaginary, contemporary corporate architecture plays a central role in establishing the dominance of transnational capital and in narrating flexible accumulation as a 'natural' or 'real' existing thing (Castoriadis and Curtis, 1997b, page 9). Functioning as a totem for flexible capitalism, new corporate architecture 
combines the creation of a new set of use values [increased ceiling heights, networking infrastructure, daylight exposure, and 'flexible' workspace (Finch, 1992)] with the institution of a new set of symbolic values, thus contributing towards positing what for flexible capitalism constitutes 'importance', or 'meaning'. In doing so, it narrates a myth quite different to that narrated by the early-20th-century corporate icons. Indeed, although contemporary commissions appear at first glance to share many common characteristics with the corporate icons of the first half of the 20th century (notably the commitment to impressive design, and the way they dominate the urban skyline), they have in fact more dissimilarities than meet the eye. The previous section detailed one such dissimilarity; ie, how the commitment to 'ennobling' workers through architectural detail, which constituted one of the design virtues of early corporate icons and one of the instituted symbolic values of early-20th-century capitalism, has become a design defect for contemporary corporate spaces. The institution of a new radical imaginary through a new relationship between capital and architecture also extends the lack of commitment to employees to a lack of commitment to the city that hosts the corporate building. This new imaginary of a city-in-the-making of footloose elites and ephemeral buildings is one that poses Architecture as the ultimate flexible object available for urban speculation on the run, and the city as an entity unclaimed/ unclaimable by its citizens (Kaika, 2010).

Indeed, unlike earlier corporate icons which edified their patrons' commitment to place and inspired a sense of civic or national pride, contemporary corporate architecture institutes a new relationship between the building and the city, a relationship which renders privatised, inaccessible urban spaces as touchstones for urban renewal, and which 'naturalises' the city as the playground for transnational corporations with no interest in urban social life. Sharing little in common with what Rossi termed 'events', that is, buildings that become moments and parts of a broader dream about the city [Rossi et al (1982); see also Hays (2010) for an excellent analysis of the term], today's corporate buildings operate more as 'self-contained machines' (Tafuri, 1980), islands of development that do not have, and perhaps do not wish to have, any relationship with the city that surrounds them. These buildings act predominantly as branding objects of transnational corporations that often have no prior links to the city in which they locate their headquarters. Like its patrons, who do not engage with urban political life, this new type of architecture, which I term autistic architecture, does not engage with the city that surrounds it, and demonstrates a "pathological selfabsorption and preoccupation with the self to the exclusion of the outside world". (16) Just as for transnational elites cities function not as places of belonging but as playgrounds for conspicuous consumption and entertainment, for this new type of autistic architecture cities function not as a place of embeddedness but rather as stages for the proud display of architectural style and experimentation. In the same way that transnational elites consume cities' amenities without committing to them, the selfabsorbed, self-referential new corporate architectural objects make bold statements on the city's skyline but are, at best, indifferent to the real city that hosts them.

A prime example of this type of architecture is the building that Swiss Re, a global reinsurance giant, commissioned to Norman Foster in 2000, for its headquarters in the City of London. The building, completed in 2004, became known as The Gherkin, made a splash in the media, and raised Swiss Re's profile as a powerful new player in the City of London. However, Swiss Re sold the building only three years after it was erected, confirming that the building's raison d'être had nothing to do with Swiss $\mathrm{Re}$ 
establishing roots in London, but served instead as a successful brand maker and a speculative real estate venture for the company. The same autistic attitude towards the city is eloquently captured in an interview that architect R Viñoly gave to Russian architectural critic V Belogolovsky. The interview was conducted in Viñoly's New York office while Viñoly's practice was commissioned to design some of the residential towers for Park-City development in Moscow. In response to Belogolovsky's question whether he had had the chance to actually see the city of Moscow, Viñoly answers that he knows the city mainly through publications, but he knows very well "what Norman [Foster] is doing [in Moscow], which is enormous and probably not his best work. In the last year, I went there five or six times to see the site and to meet the project team. I have mostly been to the key landmarks and mostly at night after the meetings. But I think I have a very good smell for it. I can imagine it very well” (Belogolovsky, 2008, no page). Here Moscow, the real city, is clearly not what Viñoly's aims to engage with; his interest lies instead with how his building will converse with other architects'-the competition's-designs. The architect is interested more in the way his building will be projected against the city's skyline than in the way the building will engage with the city and with urban space as experienced by its inhabitants.

Architectural theorist Mario Gandelsonas identifies this shift of attention, from the urban fabric and the 'lived city', to the urban skyline and the 'viewed city', as an appropriate response to the need "to introduce new major urban signifiers" as 'quilting points', nodal points that can ... "fix [the] meaning and structure the signifying field [of our cities]" (Gandelsonas, 1999, page 63; see also Žižek, 1989). The elevation of the skyline to an omnipotent field that can fix the problems of our cities is also advocated by architect and theoretician Aldo Rossi, who calls for a move away from an architecture "of the public" to an architecture "for the public" (Rossi et al, 1982, page 15; emphasis added). As I note elsewhere, "the urgency to institute a new social imaginary for cities that corresponds to the desire of new urban elites has ... turned fixing the [urban] skyline into something of an obsession, a fetish, for planners, architects, developers, architectural patrons and urban authorities" (Kaika, 2010, page 471). Within this shift from an architecture of engagement to an autistic architecture, the only place left for the architect is that of the viewer and writer/scripter of the city's image against the sky, while the only place left for the public is that of the distant viewer/admirer of architecture's new autistic objects. In this new relationship between architecture and the city, New York, Moscow, London, Beijing, Paris, etc operate as the backdrop for highlighting self-absorbed and self-preoccupied objects, as curiosity shops for the display of experimentations in autonomous design.

Apart from its preoccupation with the skyline, another characteristic of autistic architecture is the change in the building's regard towards time and ruination. Early 20th century corporate icons constituted typical cases of architectural objects designed for permanence, destined to outlive both their architects and their patrons, and to act as guarantors of the continuation in time of their name and fame. In doing so, they had a lot in common with what Žižek, following Sohn-Rethel, describes as the "sublime object": ie, "an indestructible and immutable body which persists beyond the corruption of the body physical" (cited in Žižek, 1989, page 18). From the Egyptian pyramids to the Parthenon, and from the Medieval Cathedral to the Empire State Building, the history of the icons of world architecture is a history of attempts to produce timeless, indestructible objects that will outlast time, even after they undergo weathering and wear and tear. By contrast, contemporary corporate commissions are designed with a short life expectancy, and are destined, like fashion, to be at once conspicuous and disposable. Durability now becomes a defect, since no building can be seen to outlive the corporation's operations. "The nondescript office building in Silicon Valley can 
quickly adjust to new tenants, whereas the corporate monument can easily outlast the corporation, making a mausoleum of the coliseum" (Sull, 2003, cited in MacKeith, 2005, page 58). Indeed, the skyscrapers currently erected are built with a life expectancy of between twenty and fifty years, whilst most buildings are granted a maximum lease of sixty years, corresponding to an equivalent expected life cycle (Peter Wynne Rees, The City Planning Officer for the City of London, interview, 2007). A case in point is London's Paternoster Square, which was redesigned in the 1970s in a form that was meant to last for centuries, but was replaced by a new development only twenty years later. Similarly, the magnificent Pirelli building in New Haven, Connecticut, designed by Marcel Breuer in 1969, is currently under threat of demolition to give way to an IKEA development (Architecture Week 2002). The TWA Terminal at Kennedy Airport, a New York city landmark and one of the most praised modernist buildings, designed by Eero Saarinen in 1962, was also vacated in October 2001.

Unlike the corporate icons of the early 20th century, which were commissioned at best to last forever or at worst to become ruins that would "dominate the future continuously" (Speer, 1970), contemporary corporate buildings are commissioned with their death incorporated in the design process right from the beginning. Designed with an eye towards quick turnover time, the buildings that cater for the nomadic existence of today's transnational corporations are, in fact, not allowed to escape the fate that awaits every object under capitalist production. This lack of commitment to long standing is another characteristic that, alongside lack of commitment to employees and lack of engagement with urban communities, distinguishes contemporary corporate commissions from earlier corporate icons.

The aforementioned changes in the public role and life expectancy of today's 'iconic' commissions, alongside pressure for quick turnover, inevitably have an impact on the buildings' design and production process. Whilst the dream of every self-respecting early-20th-century architect was the freedom comprehensively to design every detail of his or her building, the pressure of quick turnover leads today's star architects to adopt a more corporate approach to the creative process. Modernist guru Arne Jacobsen, famous for his obsession with detail, extended his design from his buildings' fabric, to the furniture, door handles, locks, sinks, taps, showers, light fixtures, and even wall sockets. The result of this labour-intensive, comprehensive design process was that not only the buildings themselves, but almost every object within these buildings became iconised: Jacobsen's 'Oxford' chair and his cutlery designs became as iconic as his buildings. Similarly, Frank Lloyd Wright fought tooth-and-nail to keep his design vision for the New York Guggenheim intact, against fierce criticism from New York's city council, planning authorities, architectural critics, the art world, and even his patron, Solomon Guggenheim. It was “all too much for Manhattan's building-code administrators, who haggled with Wright for 15 years over the details" (Time Magazine 1959). The New York Guggenheim was granted full permission a whole fifteen years after Wright had originally designed it, and only six months before he died. Wright fought, literally until the end, to have it his way, prompting his critics to just 'wait and see'. (17) With the same commitment to uncompromisingly pursuing comprehensive design, Jørn Utzon fought to keep his architectural vision for the Sydney Opera House intact, and resigned after Sydney's authorities interfered with his original design, never to return to see completed the building that he no longer recognised as his own.

(17) During the inauguration, Mrs Wright's statement amplified her husband's status as an uncompromising artist, by expressing doubt that Wright would ever have shown up, had he been alive. "He was too great an artist", she stated firmly, "to forgive the slightest transgression in a creative work" (Time Magazine 2 November 1959). 
A very different attitude, however, characterises contemporary architectural production. By losing its status as social art, architecture also lost its ability to pursue totalising design ideas and ideals. As McNeill (2005b, page 501) notes, "the intensification of the accoutrements of globalization ... have fundamentally altered the relationship between architect and city". The "growing complexities in the production of architecture constitute a dramatic shift that many [architects] either failed to notice or became resigned to" (Larson, 1993, page xi). A case in point is Norman Foster's conforming acceptance of his clients' decision to contract the design of the interior space of the Swiss Re building to a another design practice (Bennett Interior Design), after a competition whose long list numbered thirty-two entries, including Foster and Partners. In fact, most large architectural practices are today contracting out stages of the creative process and/or have established a strict division of labour in their design studios. In 2007 the studios of Zaha Hadid, Rem Koolhaas, Norman Foster, and Richard Rogers were employing more than 100 designers each across the world, having instituted an unprecedented global division of labour in architectural creation, but also, arguably, an unprecedented alienation in the design and production process. Even Jean Nouvel, one of the few remaining agitators in the field, who still holds on to a vision of architecture as social art and to his own role as a public intellectual, stated soberly: "Je suis un activiste de développement durable! Mais c'est le client qui décide" (I am a sustainable development activist! But it is the client who decides) (Le Chatelier, 2006, page 48; author's translation).

The repetition of successful architectural design forms across the world testifies further to the alienation of the design process. Frank Gehry's designs (see figure 2) for the Peter B Lewis Building at Cleveland, Ohio (2002), for Los Angeles' Disney Concert Hall (2004), and for the Marqués de Riscal winery extension at Elciego, Spain (2006), appear to be serial reproductions of an admittedly impressive original design: the Bilbao Guggenheim (1997). Similarly, the bullet-like form of the Swiss Re Tower designed by Foster and Partners (2004), is repeated by the same or other architects in different locations and contexts across the world: from Barcelona's Torre Agbar, designed by Ateliers Jean Nouvel (2005), to Chicago's Spire, designed by Santiago Calatrava (construction halted). Rem Koolhaas and OMA also repeat similar forms

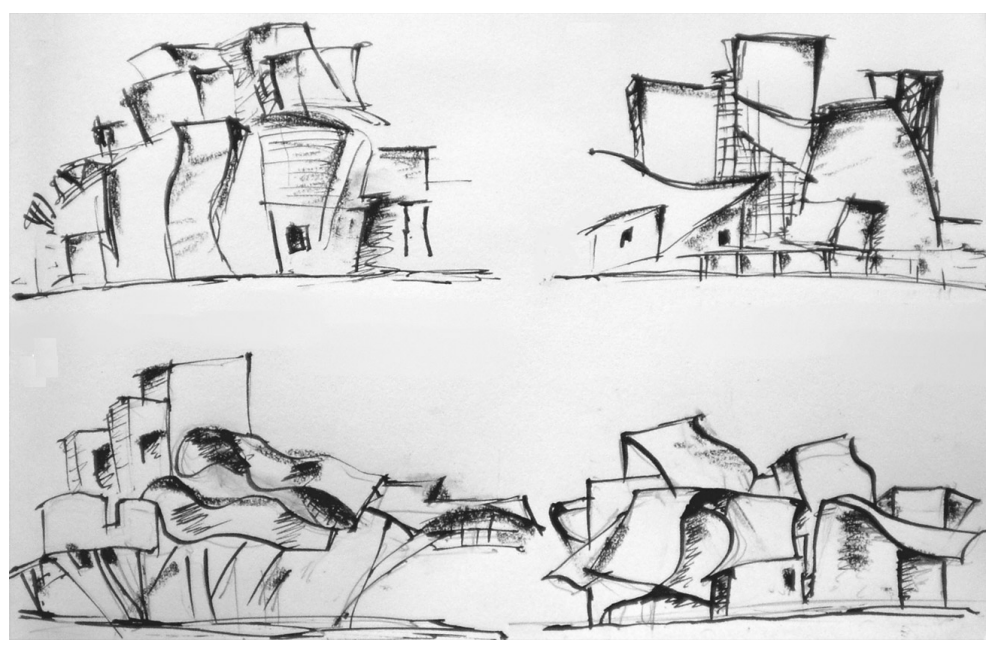

Figure 2. Repetition of successful design forms: the same design code expresses a multiplicity of meanings in different social and geographical contexts. Clockwise from top left: Frank O Gehry's Bilbao Guggenheim (1997); Los Angeles's Walt Disney Concert Hall (2004); Peter B Lewis Building, Cleveland, Ohio (2002); Marqués de Riscal winery extension, Elciego, Spain (2006) (source: author's impression). 
in Beijing [China Central Television Tower (CCTV), 2010] and Dubai (Porsche Design Towers, incomplete), and are documented to have transposed the design model from one unrealised commission to a new commission with very little change (Yaneva, 2009a; 2009b). Sudjic also notes that "Richard Meier builds essentially the same building in Frankfurt and The Hague" (Sudjic, 2006, page 76). Despite the 'star' status of these architects, their uncanny replicas of successful earlier models can hardly be described as 'original'.

Of course the repetition of similar architectural forms across the world by the same or different architects is not a new phenomenon. Many modernist gurus, amongst them F L Wright and Le Corbusier, crusaded for an architecture that could deliver mass produced, efficient 'machines for living in'. However, the commitment of modernist design to deliver inexpensive, mass-produced buildings for all is quite distinct from the claim for uniqueness accompanying mass-produced contemporary commissions. Whilst Le Corbusier's Unités d'Habitation were designed to be cheap, mass produced, and ephemeral and were promoted by their architect as such, the Swiss Re Building, the Walt Disney Concert Hall, the Marqués de Riscal winery extension, etc also repeat successful architectural forms, yet, stake a claim to uniqueness and iconicity. What Jacobs (2006, page 12) described as the "anonymous and bureaucratized middling modernism" that buried the architect "deep in the institutional framing" can be found again in late capitalism in the making of the mass-produced, but supposedly unique, corporate buildings. The glamorisation of architects, and their elevation to star status, comes hand-in-glove with the loss of their social role as master minders of urban social change. Whilst architects lose control of the role of the creative genius in the production process of their buildings, an unprecedented number of disputes and litigations over architectural design ownership and copyright proliferate. The litigations between Norman Foster and his now estranged ex-partner Ken Shuttleworth over the 'true' ownership of the Swiss Re design is well documented (Iredale, 2004; Popham, 2005), as is Rem Koolhaas's long and bitter legal battle against his own student over architectural copyright (Yaneva, 2005).

The production of 'serial objects' that nevertheless claim originality resembles what Piper terms the deformation of the art object. "Faced with the pressures of overproduction", Piper notes, "the artist has a few alternatives, besides that of simply refusing to meet all of these demands. She may produce shoddy work; or she may modify the product in ways that make it easier to produce; or she may employ others to make the work for her" (1985, page 37). The yielding of architecture's creative process to economic return, and the recurring use of the same code to express a multiplicity of meanings in different social and geographical contexts, alongside the other characteristics of autistic architecture which I have discussed in this section, put under serious scrutiny the status of contemporary corporate commissions as 'iconic'.

\section{Becoming iconic: more by ritual than by design}

Leslie Sklair defines iconic architecture as buildings and spaces that are famous and known to the general public, but which also have a "significant symbolic/aesthetic meaning attached to them" (2005, page 485). Jeffrey Alexander endorses the same point when he notes that "iconic consciousness occurs when an aesthetically shaped materiality signifies social value" (2008, page 782). Indeed, turning a building into an icon has always involved more than just design quality or a well-known signature: it has always involved complex social, cultural, and economic practices that would confer agency upon the building, and convert it into a powerful signifier of a social order ( $\mathrm{Z}$ Castoriadis, 2003). The aura that an art or architectural object possesses - the unique status and mystique that induces awe and admiration to the viewer (Benjamin, 1999 [1936]) — cannot 
be attributed to the design quality of the object per se. It is linked more to the conditions of its production, its relation to cultural values, the structures of power that produce and maintain its exclusive character, its line of ownership, and the way in which it is passed on to the next generations (Benjamin, 1999 [1936]).

Indeed, from St Paul's Cathedral to Basilique du Sacré-Cœur, and from the Eiffel Tower to the Empire State Building, the embeddedness of a building into cultural social practices is more significant than its design quality for granting it iconic status. Even in ancient Egypt, where the importance of architecture was so deeply inscribed into cultural practices that the architect was esteemed as second only to the Pharaoh in the social order, still, the iconic character of the pyramids was never considered god given or subject to the architect's good design alone (Meskell, 2005). It was the burial rituals performed inside the Egyptian Pyramids, the ritual offerings to Athena performed inside the Parthenon, the royal weddings performed inside and the public executions performed outside St Paul's Cathedral, that brought these buildings squarely into everyday experience, imbued them with meaning, and conferred upon them the status of the 'icon'. Ancient, medieval, or contemporary buildings that now hold an indisputable 'iconic' status gained this status only after becoming ritualized through a complex set of sociocultural practices. The Eiffel Tower and the Pompidou Centre were both much hated originally by the Parisian public. French authors Emile Zola and Guy de Maupassant both protested against the Eiffel Tower, which the latter described as "an odious tower of extreme bad taste" (Henley, 2003, no page). However, these buildings became ritualized as part of the Parisian landscape and public imagination after decades of systematic and persistent association with key cultural and public events. Equally, for early-20th-century corporate buildings, it was the way in which they became embedded in urban public life and the role they played in narrating the myth of a better urban society that granted them iconic status. It was less by design and more through ritual that these buildings gained their iconic status; through public events, public art displays, and public performances in the Rockefeller Center, through cinematic representations of the Empire State Building as the apex of the world, through media and art references to the World Trade Center as the epitome of the economic and social reign of the United States. Those early corporate icons became so much part of the American public imaginary, that they provided the inspiration for A C Gilbert's famous Erector Set (1912), a Meccano-type toy that allowed a whole generation of American children to replicate skyscraper models at home, in a gesture that appropriated the icon for the everyday.

But if the architectural icon is indeed not just an object designed and constructed to stand out visually, but also one that engages with the city that surrounds it - an object which is embedded in social and cultural ritual, enhances public space, inspires civic pride, and by doing so escapes ephemerality - then contemporary corporate architectural commissions cannot belong to this category. Despite their depiction as 'iconic' in media representations, the characteristics detailed in the previous section (the alienation of the design process, the bourgeoning uncanny imitations of successful design originals, the lack of commitment to employees and to place, the ephemeral character and quick turnover time, and the subordination of the creative process to the economic process) dissociate contemporary corporate buildings from the category of 'iconic' buildings, and place them instead closer to the category of objects of mass production, to what Baudrillard depicts as "serial objects ... stuck fast in their quest for uniqueness" (1996, page 161). Disassociated from powerful social and cultural rituals that would determine them as 'unique' and would assist their public interpretation as special, the mechanically reproduced contemporary corporate commissions quickly undergo a process similar to the one that mechanically reproduced 
objects of art underwent after industrialisation: they lose their auratic distance from the viewer, a distance that is central for granting them kudos and their 'iconic' character (Benjamin, 1999 [1936]).

Interestingly, however, the further architectural production moves away from the notion of the 'icon', the greater effort is put in by contemporary architectural patronage to elevating mass-produced architectural objects into ritualised global landmarks. Indeed, rarely has the desire and effort to elevate particular buildings to the status of 'icons' been as strong and as well orchestrated at a global scale as it is today. Commissioning 'star' architects who will compete over the next loud design is only one of many rituals used to elevate ephemeral contemporary corporate buildings to the status of 'icon'. In what follows, I shall identify the process through which contemporary architectural objects become 'iconised', or, to paraphrase Pardo (2006), the process through which 'marks of ignominy' are turned into 'signs of distinction'.

\section{Turning the ephemeral into the sublime: the need for phantasmic seduction}

As noted above, the great monuments of humankind have acquired their iconic status through an extensive process of ritualisation into everyday life. By contrast, many contemporary corporate buildings function as secluded autistic spaces and are hardly embedded in cultural practices or public rituals. So, what is the process through which contemporary corporate buildings become iconised? I shall argue that, as the imaginary significations of flexible capitalism fail to act as 'events' or to add value, meaning, or synthesis to urban space and public life - the contemporary imaginary borrows substance instead from "the investment of phantasy, [and] the ascription of value" that lead to an "autonomization" of its symbolic elements (Castoriadis, 1987, page 159). Conferring agency upon today's autistic architectural objects relies on a well-orchestrated "phantasmic seduction" (Žižek, 1989, page 1), a process through which iconic status is conferred upon buildings not through their performative participation in public ritual, but through the imposition of levels of abstract ritualisation. In this process, it is not the general public but the media, architectural critics, local authorities, developers, and architects who participate. This abstract ritualisation, which is witnessed only by a fraction of society, is part of the imaginary institution of a new "universe of symbols". Below, I identify a number of instances of the process through which this abstract ritualisation is enacted.

\subsection{Media rhetoric and representational practices: architecture as religious experience}

Media rhetoric and representational practices have become central performative moments in conferring agency upon contemporary buildings. Through enigmatic articles and star architectural critics' orations, the public is asked to do with architecture today what Pascal suggested doing with religion: "even if you do not believe, kneel down, act as if you believed, and belief will come upon you" (cited in Žižek, 1989, page 6). Even if the next skyscraper to be erected in London's or New York's skyline does not relate to anything that Londoners or New Yorkers can identify with, the city's public is nevertheless bombarded by so many expert opinions on its significance, sublime design, and aesthetic value, that when it is finally erected, all that's left to do is 'kneel down' and admire it, hoping that the subsequent ritualisation of the building into the city's everyday life might justify this belief. During the public enquiry over the Walkie Talkie, a yet-to-be-erected London Tower, Francis Golding from Land Securities exemplified this attitude when he prophesised that: "[the] Walkie Talkie [will] become as iconic a part of London's skyline as the Swiss Re Gherkin. ... the Rafael Viñoly-designed tower [will] become a loved symbol of London" (Clift, 2007). Hardly known, let alone loved by Londoners, the Walkie Talkie is here depicted as iconic 
even before it is granted planning permission. Its public defender requests London's authorities to accept the celebrity status of the architect as a testimony to how well the building will fit into the city, and as proof of the 'iconic' status that controversial design is expected to acquire. The same spirit of make believe iconised the Shard of Glass and its architect, Renzo Piano, in newspapers, glossy magazines, and architectural review articles before it was erected. The Independent noted: "something ... significant [is] simmering north of the Thames...; something that transcends iconic architectural statements, and is poised to deliver a key step-change in vertical city planning. We're talking size, and we're talking clumps. The Shard, designed by the brilliant Renzo Piano, may prove to be a building of the highest quality and drama" (Merrick, 2004, page 12). Another unbuilt project, the Minerva Tower, received equal praise: "Minerva PLC's major redevelopment will feature an elegant tower concocted by Sir Nicholas Grimshaw, and there's no doubt that this will be a landmark building" (Merrick, 2004, page 12). Tour Phare, Paris's response to London's Gherkin, commissioned to Thom Mayne in 2006 (estimated completion 2014), was ascribed by the media the power to "humanize a most inhuman space [La Défense]", whilst its architect pre-empted its iconic status by declaring he was "not intimidated by creating a modern icon for this iconic city" (Stamberg, 2007, no page). More often than not, size and glitz also feature as guarantors for a building's 'iconic' status: "glamour is one of the main drivers. On a big site you can create an iconic identity that can add to the image of the whole site-and indeed the whole city" (McGhie, 2005, page 15).

This way of insinuating 'iconic' status to yet-to-be-erected buildings, this imaginary institution of reality as something that "exists only to the extent it is recorded" (Castoriadis, 1987, page 159) is reminiscent of the scheme that Robert Boyle followed in the 17 th century to endorse his scientific discoveries as real 'facts'. As a means of proving to the public that his experiments on the air pump validated 'real' facts of nature, he mobilised not logic but the testimonies of 'respectable', 'well-to-do gentlemen', who were invited to witness the experiments and subsequently endorse his discoveries as 'real' (Latour, 1993, pages 17-18). Similarly, the celebration of contemporary corporate buildings by intellectual and economic elites as 'iconic', and the fact that they are designed by 'star' architects, requests the public to endorse their 'iconic' status as 'real'.

\subsection{Nicknaming buildings: toy architecture and curious objects}

A metonymic symbolic process of nicknaming buildings also contributes towards enacting an objectification and ritualisation of contemporary corporate architecture without the participation of the city's public. Nicknaming has always been a common public response to much-loved and much-hated buildings alike. However, what is new and important for the argument here, is that today's corporate skyscrapers are nicknamed not by the city's public, but by developers themselves. They are nicknamed not after but before they are erected. Nicknaming buildings promotes them as toy-like, curious urban objects that could trigger affect from the part of the urban public.

London pioneered a frenzy of nicknaming yet-to-be-erected buildings in the 1990s and 2000s, with names 'invented' by developers or planners as part of the buildings' marketing strategy, and as part of the efforts to win the public's approval by endearing them: "no sooner was [the] lovable curving profile [of the Swiss Re building in London] exposed beneath the scaffolding than Lord Foster's $590 \mathrm{ft}$ skyscraper in the City of London became the Gherkin. The Gherkin it remains, and it is as the Gherkin that Londoners have taken it to their hearts" (Popham, 2005, page 28). In London again, the Leadenhall Tower was given the endearing name of London's Cheese Grater, and 20 Fenchurch Street was nicknamed the Walkie Talkie before it reached ground zero 
of construction, whilst Bishopsgate Tower changed nicknames each time its ownership changed hands (Helter Skelter, Pinnacle). London's public may not be able to relate the Swiss Re building or 20 Fenchurch Street to something in their everyday urban experience, but London's Erotic Gherkin, or the Walkie Talkie appeal directly to the imagination.

The objectification and ritualisation of nonexisting buildings through metonymic referencing are complemented by the production of photorealistic media images, which project buildings into the city's skyline as if they were already fully embedded onto the urban landscape. These images are produced by specialised architectural firms and have become a key marketing strategy for developers and an integral part of the phantasmic seduction that tries to ritualise nonbuilt architecture. The significance of photorealistic images in asserting a commission's legitimacy over urban space is such that the production of these images has developed into a full blown specialisation over the last ten years, a specialisation whose aim is not so much to assist architects with the design process as it is to help developers and planning authorities 'sell' the building to the general public. John Hare, cofounder of one of the most successful practices in London, notes that: "[when we set up this practice], we thought that what we were doing was to provide some specialist advice to architects and that we would be in effect a consultancy not only on visualisation, but also on several aspects of architecture ... [but] ... 10 years ago we came to realise that what we were doing meant that we would collaborate less directly with architects and more with developers and occasionally with local authorities" (interview, John Hare, 2007).

\subsection{Hollywood architecture: the architect as a media persona}

The phantasmic seduction that ritualises contemporary corporate buildings also recruits the persona of the architect herself or himself. Under increasing pressure to match their design expertise with public relations skills, architects appear in interviews and airbrushed photographs that sustain and accentuate their 'star' status and fuel the phantasy that imbues their buildings with social meaning. Within this context, Rem Koolhaas is depicted as "tall and gaunt as a saint in an altarpiece, [with] a taste for edifying pain" (Wired, 2000, no page). Similar religious and star connotations ring when Zaha Hadid is described as "the first architect to be so blessed since Mies" with "so distinctive a name [that it] might just grant [her] entry to the glitzy cadre of the mononomial: Elvis, Arletty, Sting" (Meades, 2008, page 65). The press reserves equally revering adjectives for Norman Foster who is described as "a snappy dresser with a face like a sculpted Roman bust" (Northedge, 2007, page 10) who "flies his own plane to meetings on the continent, spends a month each year at his St Moritz bolthole training for the annual Engadin Valley cross-country skiing marathon, and lives in a glazed riverside penthouse above his practice's Battersea offices (in a building he designed himself)" (Cargill Thompson, 2005, no page). Rem Koolhaas promotes his own myth further, by drawing up a genealogy of iconic buildings across the centuries, with his own design for the China Central Television Tower (CCTV) featuring next to the Egyptian Pyramids, to Gaudi's Sagrada Familia, and to Eiffel's Tower. By placing his own edifice on a par with the great monuments of world architecture, Koolhaas is of course doing what he does best: he is being ironic. However, at the same time, he is also consciously amplifying his own myth. This is not simply an ironic statement by a star architect; it is an attempt to build kudos and secure a place in history within a climate of cut-throat international competition over architectural commissions. It is no coincidence that Rem Koolhaas and Daniel Libeskind, two amongst a handful of contemporary international star architects, started their careers as journalists, and only came to practise architecture after they gained international media recognition. 


\subsection{Marketing architecture: exchange value as phantasmic seduction}

A further, and perhaps most effective, ritual employed in the process of 'iconising' buildings, is the public announcement of the price a building can fetch as a commodity in the global market. For works of art, elevation to mythic status by virtue of announcing their market value has been common practice for a number of years now. When, in 1987, Van Gogh's Irises was auctioned at London's Sotheby's to an Australian investor for a then world arts market record price of $\$ 49$ million (Thornton, 2008), the figure that paraded in the global media contributed to inflating further the masterpiece's exchange value. In a similar manner, Damien Hirst's diamond-encrusted human skull, titled For the Love of God, came with a price tag of $£ 50$ million. It originally remained unsold, but made a world media splash when it was sold in 2008 to an investment group (Thornton, 2008). However, there is a catch in both of these cases of record price arts sales. In the Australian investor's case, he was able to purchase Van Gogh's Irises at this price only with the assistance of Sotheby's themselves, who offered half the money in the form of a loan; in the case of Hirst's diamond skull, the 'group of investors' who purchased the artwork included the artist's own company. In general, over the last decades, strategies for creating fictitious values for objects of art run in parallel with the elevation of these objects to a mythical status. But for architectural objects, their parading in the media by virtue of their exchange value in a globalised real estate market is a relatively recent phenomenon. The Swiss $\mathrm{Re}$ building gained a prominent place in the imaginary of Londoners when it was sold in 2007 for $£ 600$ million, a then record price for a building in London's financial district (Glancey, 2007). Bishopsgate Tower (The Pinnacle) previously owned by Union Investment, received equally wide media attention when it was sold as an unbuilt project to Arab Investments for over $£ 1$ billion (Pickard, 2007, page 14). Similarly, the publicity that Dubai's or Kuala Lumpur's skyscrapers received in recent years was fuelled not only by the design qualities of these buildings, but mainly by speculative practices involved in their construction and by their unattainable asking prices. As a commodity's unattainable exchange value has the perverse effect of rendering it into fetish object and a wish image (Buck-Morss, 1995), the elevated market value of contemporary corporate buildings contributes to the abstract ritualisation that inscribes them in the public imagery as 'iconic'.

\subsection{Screening out the city's public: creating an atmosphere of forced exclusiveness}

As noted in the previous section, earlier corporate icons appropriated the language of public space to create ritualised private spaces (Twombly, 1996). Their contemporary counterparts, however, appropriate the language of the fortress instead, and assert their kudos by projecting an air of mystique and 'enigma' (Jencks, 2004), and by promoting the image of an unreachable object of desire that cannot and should not be touched by the general public. Indeed, most contemporary corporate commissions have their interiors carefully sealed off from the public gaze, and nobody-unless on business - is allowed to access their lobbies. Although recently justified in the name of security (Coaffee, 2003; Graham, 2004), this practice is central in asserting an air of exclusiveness and privilege for everyone who is granted access to the buildings. These buildings do feature restaurants, cafes, and lobbies decorated with exquisite artwork, but access to these spaces is normally granted only to those who conduct business there.

The autistic attitude of interior spaces extends to the open space around these buildings. Although many of London's new corporate buildings were granted planning permission under the condition that they would provide public space, when these 'public' spaces are materialised, they are in fact privatised, inaccessible, or 
unwelcoming to the urban dweller. Even photography is forbidden in the immediate vicinity of many of these buildings, allegedly in the name of breaching architectural copyright (Hasslehoff, 2005). Although most Londoners would identify The Gherkin as a photogenic picture of the city's skyline, very few have actually accessed the building itself, or have come near the open space in its immediate vicinity. The building is thus identified as a point in the skyline that one can look at from a distance, but does not relate to anything in the urban dwellers' everyday life.

The inaccessibility both of the buildings' interior spaces and of the spaces in their immediate vicinity is another level of ritual abstraction that, combined with their unattainable exchange value, contributes to turning contemporary corporate commissions into objects of desire and wish images. The queues outside the Swiss $\operatorname{Re}$ on heritage day (the only day of the year that the general public of London is granted access to the building) have an immediate sensationalising effect and receive considerable media attention. The practice of generating fictitious demand to see the building by granting access to it for one day a year only is reminiscent of retail marketing strategies whereby controlled entrance (often by locking doors) produces unnecessary queues outside a shop. The queues, in turn, operate as an effective signifier, at the street level, that something special might be taking place inside. After the long wait, the customer feels compelled to feel privileged for being granted entrance, but cannot help registering that he/she finds him/herself inside a banal retail space, browsing banal commodities. Similarly, upon entering the Swiss Re building, the pang of disappointment at the blunt, surgically clean interior spaces, shares nothing in common with the delight of the senses upon entering the Rockefeller, the Empire State, or the Chanin buildings.

Lacking place loyalty or a ritualised embeddedness in urban social life, and sealed off from the public gaze, contemporary corporate 'icons' are open to symbolic overdetermination. In her imaginative illustrations for Charles Jencks's book Iconic Building: The Power of Enigma (2004), Madelon Vriesendorp attaches a playful and ironic multiplicity of meanings to Amanda Levete and Jan Kaplicky's Selfridges at Birmingham, which becomes a tongue, a dress, breasts, a monster, and the inside of a whale! In Vriesendorp's playful metaphors, Foster's Swiss Re building is also depicted not only as a gherkin, but also as a brain, phallus, screw, bullet, finger, missile.

Jencks (2004) performs his own search for a meaning in contemporary 'icons' and locates it in the cosmic, the supernatural order. Architects today, he asserts, in their effort to reconcile often opposing demands, resort to the 'power of enigma': ie, they produce 'enigmatic' signifiers that suggest many meanings, without committing to any of them. To Jencks, the contemporary global icon has a "more difficult task to perform than the traditional monument: in need of instant fame, it has to be both provocative and practical, an amazing piece of sculpture that can speak to diverse audiences across the world" (2004, cover page). According to Jencks, these buildings have a difficult task to perform as their reach and ambition goes beyond the petit locales of London, Bilbao, New York, Paris, Kuala Lumpur, or Dubai. Jencks's, however, is a generous reading as it makes a virtue out of the way contemporary architecture relates to an internationalised scene of circulation of money and power; but it does not succeed in adding meaning or value to people's everyday lives. This is more of an aesthetic reading that fails to engage with the social and economic processes that produce today's global 'icons'. Jencks's direct comparison of the alleged enigmatic power of contemporary 'icons' with that of the ancient pyramids is a gesture and an explication that takes architecture out of its historical, social, and geographical context. As we have seen, any 'enigmatic power' that the pyramids may exert on us today is mainly due to the fact that we are not (and cannot be) familiar fully with the rituals that made them part of 
the everyday life of ancient civilisations (Meskell, 2005). However, to the extent that the imaginary in the form of architecture, art, or language, is not a mere reflection of the world but also the means through which each society, each epoch, "constructs, constitutes and creates" its own world (Castoriadis and Curtis, 1997b, page 5), any 'enigmatic power' that contemporary architecture may exert on us is that of the discomfited existence of autistic objects, which ultimately fail to provide a new collective myth that would add value and meaning to disenchanted urban societies under late capitalism.

As the "capacity of contemporary society to represent itself is becoming increasingly flattened out" (Elliott, 2002, page 159), contemporary imaginary significations fail to provide "the norms, values, and motivations" which could "make a society function ... in a liveable state of 'equilibrium" (Castoriadis, 1982, page 262, cited in Elliott, 2002, page 159). Within this context, the overproduction of 'iconic' architecture today is not only symptomatic of changes in the institutions and elites that hold society together; it also becomes a way of providing an architectonic 'fix' to the urgent need to posit meaning and value and institute a new imaginary for a society in search of a new identity, and for corporations, institutions, and cities in need of rebranding.

\section{Beyond the architectonic 'fix': the changing social role of architecture}

Conceptualising architecture as a totem in the imaginary institution of social relations, this paper has argued that the significant changes in the ethnography of urban elites after the 1970s instituted a new relationship between private capital and architecture. If place-loyalty used to be the driver of urban change and renewal in the early 20th century, with urban tycoons funding monuments to their life and their city, today it is the evasion of place-loyalty alongside urban managerial practices (Brenner, 1998; Brenner and Theodore, 2002; Harvey, 1989) that fuels architectural production and urban renewal. The replacement of 'traditional' place-loyal urban elites with a new generation of footloose transnational elites can account for the banalisation of early-20th-century corporate icons, and the proliferation of a new generation of corporate buildings that aspire to be the next global 'icon'. However, contemporary corporate commissions operate more as self-referential monosemantic autistic objects, which enhance the urban skyline, but make no attempt "to reclaim, recommend or re-impose meaning" for cities (Tafuri, 1999 [1973], page 123).

The end of architecture as 'social art', the conviction that architecture cannot operate outside and beyond the logic of capital accumulation, can perhaps be seen as a 'sobering up' of architectural practice, a newly found pragmatism. It can even be celebrated as the most 'honest' phase in architectural production under capitalism, in the same way that Damian Hirst's $£ 50$ million diamond-clad skull constitutes perhaps the most sincere art object ever constructed for a capitalist art market. Maybe this is the only honest response an artist/architect can give today to a system that makes or breaks him/her, but which he/she nevertheless needs to survive. If we were to offer a generous reading of contemporary architectural production, we could condone it as a "desperate attempt to infuse pre-modern enchantment into the process of modernization" (Žižek, 1989, page 132). We could, indeed, celebrate the end of the architect as social engineer and urban masterminder as a shift towards the 'democratisation of the genius' (Bell, 1976).

However, architecture's new 'pragmatism' comes at a cost. Like the diamonds glittering over death in Hirst's skull, the impressive design of contemporary architecture acts as the aesthetic replacement of a lost collective myth, an attempt to infuse thaumaturgy in an era in which even artists have forgotten how to dream about alternatives (Žižek, 1989). Seen in this light, the 'pragmatism' of contemporary architecture can 
hardly be distinguished from a deeply seated cynicism, and from the rise of a spineless architecture interested in little more than to please its clients and the media. Philip Johnson, the once-great advocate of architecture as 'social art', declared his contentment that, at seventy-two, he could finally "think in terms of pleasing myself and not reforming society or developing any kind of moralist vision about the impact of my work on society" (cited in Giovannini, 1984, page H29). Architects and architectural critics alike choose to operate, increasingly, as agnostic intellectuals, shying away from social responsibility, restricting their interventions to "aesthetic and stylistic reflections devoid of any analysis of the real" (Nouvel, 2005, no page), and sheltering in the concept of architecture as a 'cosmic' art, a 'pure art' that can dwell outside society, but not outside the logic of capital accumulation.

Architectural production has always been central in the imaginary institution of societies and, as this paper has shown, today's supposedly 'pure' or 'cosmic' architecture plays as pivotal a role as ever in instituting a radical imaginary that establishes new power relations and 'naturalises' social, economic, and cultural values under flexible capitalism. Stripped from ideological vestiges, but with an increased emphasis on the spectacular, today's autistic architecture promotes 'flexibility' and end of placeloyalty as 'natural', or 'real' existing things, and has abandoned any claim to restoring meaning or synthesis to cities. But if, as MacKeith eloquently puts it - and as recent history has proven - today's corporations are actually not 'flexible', but rather 'dissolving', and in doing so they "become the 'dissolving agents' of our cities" (MacKeith, 2005, page 44), then today's lack of desire to fashion alternative consciousness (Bell, 1976, page 16) and to dream alternative futures has serious material effects. As the spectacular changes in urban skylines across the world are accompanied by transmuted urban streetscapes with blind spots and inaccessible spaces, F L Wright's aphorism, that whilst a physician can bury his mistakes, the architect can only advise his clients to plant vines, is not enough. As Huxtable concedes, "when architects put themselves into the same category as art personalities and ignore every way that their art touches the world, it's not socially responsible. It has a bad physical effect" (Ada Louise Huxtable, cited in Lopate, 2006, no page).

If we accept that any change, nay, history itself, is inconceivable without a radical imaginary, and if architecture plays a central role in the production of such an imaginary, then a historical moment whose radical imaginary is stalled in delivering ephemeral autistic architectural statements begs for a call to salvage architecture as the spatial expression of the perpetual quest to "sweep away all fixed, fast, frozen relations" (Marx, 1935, page 210), and as the social art that can give material form to dreams for an alternative future. However, if there is a contemporary project for autonomy to salvage, this can only be open ended. While peeling away the illusions of mastery, we still have to "create the good" and we have to do so "under imperfectly known and uncertain conditions" (Castoriadis and Curtis, 1997a, page 400, emphasis added). Castoriadis's work opens up a way to theorise change, but needs to be updated, and further substantiated. Rethinking architecture as a social art requires systematic enquiry and engagement that could bring forth alternative imaginaries.

Acknowledgements. A British Academy Small Research Grant, and a Visiting Fellowship at Queen Mary Graduate School in the Humanities and Social Sciences, University of London, supported this research. I am grateful to Geography colleagues at Queen Mary and to my colleagues at the School of Environment and Development, University of Manchester, for their comments, and for providing an environment conducive to academic writing. Thanks also to the Oxford University Centre for Geography and the Environment for supporting the early stages of this work. Special thanks to Luca Ruggiero, Michael Hebbert, Erik Swyngedouw, Graham Bowden, Maria Mantouvalou, and to the editor and anonymous referees for their constructive comments. 


\section{References}

Abalos I, Herreros J, Ockman J, 2003 Tower and Office: From Modernist Theory to Contemporary Practice (MIT Press, Cambridge, MA)

Alexander J C, 2008, "Iconic consciousness: the material feeling of meaning" Environment and Planning D: Society and Space $26782-794$

Anonymous, 1998, “The Wright stuff: Frank Lloyd Wright's legacy of architecture" USA Weekend 6-8 November, http://www.usaweekend.com/98_issues/981108/981108wright2.html\#johnson

Antoinette M, 2001, "In the region/New Jersey; seeking a prince to take over a corporate palace" New York Times 11 November

Aragon L, 1924, "L'armoire à glace un beau soir", in Le Libertinage Ed. L Aragon (Gallimard, Paris)

Aragon L, 1994 [1926] Paris Peasant (Exact Change, Boston, MA)

Architecture Week 2002, "IKEA threatens Breuer icon", 13 November

Baudrillard J, 1996 The System of Objects (Verso, London)

BBC News, 2003, "Reuters says goodbye to Fleet St", http://news.bbc.co.uk/go/pr/fr/-/1/hi/business/ 3132716.stm

Bell D, 1976 The Cultural Contradictions of Capitalism (Basic Books, New York)

Belogolovsky V, 2008, "Rafael Vinoly: interview by Vladimir Belogolovsky", 1 September, available at http://www.archi.ru

Benjamin W, 1999 [1936], “The work of art in the age of mechanical reproduction”, in Illuminations (Pimlico, London)

Berman M, 1983 All That Is Solid Melts Into Air: The Experience of Modernity (Verso, London)

Booth R, 2001, "Tall buildings policy angers city chiefs" Building Design 15 June, 14913

Bouzarovski S, 2009, "Building events in inner-city Gdańsk, Poland: exploring the sociospatial construction of agency in built form" Environment and Planning D: Society and Space 27 $840-858$

Brenner N, 1998, "Global cities, glocal states: global city formation and state territorial restructuring in contemporary Europe" Review of International Political Economy 51 - 37

Brenner N, Theodore N, 2002 Spaces of Neoliberalism: Urban Restructuring in North America and Western Europe (Blackwell, Oxford)

Buck-Morss S, 1995 The Dialectics of Seeing: Walter Benjamin and the Arcades Project (MIT Press, Cambridge, MA)

Burns K, 1998, “The master builders" Vanity Fair (November) pp 302-318

Cargill Thompson J, 2005, "He built this city: the Time Out interview: Norman Foster" Time Out 23 March, pp $18-20$

Castoriadis C, 1982, "The crisis of Western societies", in The Castoriadis Reader 1997 Ed. D A Curtis (Blackwell, Oxford) pp 253-266

Castoriadis C, 1987 The Imaginary Institution of Society (Polity Press, Cambridge)

Castoriadis C, Curtis D A, 1997a The Castoriadis Reader (Blackwell, Oxford)

Castoriadis C, Curtis D A, 1997b World in Fragments: Writings on Politics, Society, Psychoanalysis, and the Imagination (Stanford University Press, Stanford, CA)

Castoriadis Z, 2003, "Instituting public space", in Rethinking Radical Spatial Approaches. Seminars of the Aegean, Naxos Eds C Hadjimichalis, D Vaiou, Department of Urban and Regional Planning, NTUA, Harokopio University of Athens, Aristotle University of Thessaloniki, Naxos, pp $187-194$

Clift P, 2007, "Walkie Talkie would become loved symbol of London" EGI News 8 March

Coaffee J, 2003 Terrorism, Risk and the City (Ashgate, Aldershot, Hants)

Domosh M, 1990, "Those 'sudden peaks that scrape the sky' - the changing imagery of New York's first skyscrapers", in Place Images in Media - Portrayal, Experience, and Meaning Ed. M D Savage (Rowman and Littlefield, Lanham, MD) pp 9-30

Elliott A, 2002, “The social imaginary: a critical assessment of Castoriadis's psychoanalytic social theory" American Imago 59141 - 170

Ethington P J, Schwartz V R, 2006, "Introduction: an atlas of the urban icons project" Urban History 33 5- 19

Fainstein S, 1994 The City Builders: Property, Politics and Planning in London and New York (Blackwell, Oxford)

Finch P, 1992, "Towards an urban architecture", in City Changes: Architecture in the City of London 1985 - 1995 Ed. R Burdett (Architecture Foundation, London) pp 17 - 19

Gandelsonas M, 1999 X-urbanism: Architecture and the American City (Princeton Architectural Press, New York) 
Giovannini J, 1984, "Philip Johnson designs for a pluralistic age" New York Times (1857-Current file), page $\mathrm{H} 29$

Glancey J, 2007, "Gherkin sale leaves us in a pickle”, http://blogs.guardian.co.uk/art/2007/02/ gherkin_sale_leaves_us_in_a_pi.html

Graham S, 2004 Cities, War and Terrorism: Towards an Urban Geopolitics (Blckwell, Oxford)

Harvey D, 1989, "From managerialism to entrepreneurialism: the transformation in urban governance in late capitalism" Geografiska Annaler 71 3-17

Hasslehoff, 2005, "The Gherkin" City Noise 12 April, http://citynoise.org/article/731

Hays K M, 2010 Architecture's Desire: Reading the Late Avant-garde (MIT Press, Cambridge, MA)

Henley J, 2003, "Low-rise Paris set to scrape the sky: housing crisis forces rethink of 30-year ban on tall buildings" The Guardian 3 November

Iredale W, 2004, "Foster rival gets a Stalin brush-off" The Sunday Times 31 October

Jacobs J M, 1994, "Negotiating the heart: heritage, development, and identity in postimperial London" Environment and Planning D: Society and Space 12751 - 772

Jacobs J M, "A geography of big things" Cultural Geographies 13 1-27

Jencks C, 2004 The Iconic Building: The Power of Enigma (Frances Lincoln, London)

Kaika M, 2010, "Architecture and crisis: re-inventing the icon, re-imag(in)ing London and re-branding the City" Transactions of the Institute of British Geographers, New Series 35 $453-474$

Kaika M, Thielen K, 2006, "Form follows power: a genealogy of urban shrines" City: Analysis of Urban Trends, Culture, Theory $1059-69$

Kavoulakos K, 2006, "Castoriadis on social imaginary and truth" Ariadne 12 201-213

Koepnick L, 2001, "Redeeming history? Foster's Dome and the political aesthetic of the Berlin Republic" German Studies Review 24303 - 323

Kynaston D, 205 The City of London: Volume 4-A Club No More, 1945-2000 (Pimlico, London)

Larson M S, 1993 Behind the Postmodern Facade: Architectural Change in Late Twentieth-century America (University of California Press, Berkeley, CA)

Latour B, 1993 We Have Never Been Modern (Harvester Wheatsheaf, New York)

Le Chatelier L, 2006, "Interview with Jean Nouvel” Telerama 22 February, pp 44-48

Loos A, Opel M, Mitchell M, 1998 Ornament and Crime: Selected Essays (Ariadne Press, Riverside, CA)

Lopate P, 2006, "Ada Louise Huxtable: history” Metropolis Magazine (January)

McGhie C, 2005, "From rock bottom to sky high" Financial Times Weekend 19 November, House and Home section, page 15

MacKeith P, 2005, "The dissolving corporation: contemporary architecture and corporate identity in Finland", EVA - Finnish Business and Policy Forum, Helsinki

McNeill D, 2002, "The Mayor and the world city skyline: London's tall buildings debate" International Planning Studies 7325 - 334

McNeill D, 2005a, "Dysfunctional urbanism” International Journal of Urban and Regional Research $29201-204$

McNeill D, 2005b, "In search of the global architect: the case of Normal Foster (and Partners)" International Journal of Urban and Regional Research 29501 - 515

McNeill D, 2006, "Globalization and the ethics of architectural design" City 10 49-58

Marx K, 1935 Selected Works (Co-operative Publishing Society, Moscow)

Meades J, 2008, "Zaha Hadid” Intelligent Life (Summer) pp 62-71

Merrick J, 2004, "Architecture: the sky's the limit" The Independent 11 February, page 12

Meskell L, 2005, "Objects in the mirror appear closer than they are", in Materiality Ed. D Miller (Duke University Press, Durham, NC) pp 51-71

Miller J-A, 1991 Lacan, Jacques: Freud's Papers on Technique 1953-1954 The Seminar of Jacques Lacan, book 1, translated and edited by J Forrester (W W Norton, New York)

Northedge R, 2007, "Foster's design for his future Richard Northedge profiles the iconic architect who for the first time is bringing outside investors into the firm he has run for 40 years" The Sunday Telegraph 13 May, CITY section, page 10

Nouvel J, 2005 Louisiana Manifesto (Louisiana Museum, Humlebæk)

Pardo J L, 2006, "Never was trash so beautiful”, in Urban Distortions Ed. J L-A Blázquez (Casa Encendida, Madrid)

Pickard J, 2007, "London skyline: debate builds over plans" Financial Times 14 March, page 14

Piper A M S, 1985, "Critical hegemony and aesthetic acculturation" Nô̂s 19 29-40

Popham P, 2005, "An icon of architecture: the Gherkin goes global" The Independent 18 October, pp $28-29$ 
Rand A, 1947 The Fountainhead (Cassell, London)

Read G, 2005, "Aragon's armoire”, in Surrealism and Architecture Ed. T Mical (Routledge, London) pp $31-40$

Rossi A, Eisenman P, Graham Foundation for Advanced Studies in the Fine Arts, Institute for Architecture and Urban Studies, 1982 The Architecture of the City (MIT Press, Cambridge, MA)

Sennett R, 2001, "A flexible city of strangers" Le Monde Diplomatique (February)

Sennett R, 2007, "Capitalism and the city", http://on1.zkm.de/zkm/stories/storyReader $\$ 1513$

Sklair L, 2001 The Transnational Capitalist Class (Blackwell, Oxford)

Sklair L, 2005, "The transnational capitalist class and contemporary architecture in globalizing cities" International Journal of Urban and Regional Research 29485 - 500

Sklair L, 2006, "Iconic architecture and capitalist globalization" City 1021 - 47

Speer A, 1970 Inside the Third Reich: Memoirs (Weidenfeld and Nicolson, London)

Stamberg S, 2007, "A new tower to soar over Paris", http://www.npr.org/templates/story/ story.php? storyld $=9892526$

Sudjic D, 2006 The Edifice Complex: How the Rich and Powerful Shape the World (Penguin Press, London)

Sull D N, 2003 Revival of the Fittest: Why Good Companies Go Bad and How Great Managers Remake Them (Harvard Business School Press, Boston, MA)

Tafuri M, 1980 Theories and History of Architecture (Granada, London)

Tafuri M, 1999 [1973] Architecture and Utopia: Design and Capitalist Development (MIT Press, Cambridge, MA)

Thornton S, 2008, "Damien Hirst is rewriting the rules of the market" The Art Newspaper 17 July Time Magazine, 1959, "Last monument", 2 November

Twombly R, C, 1996 Power and Style: A Critique of Twentieth-century Architecture in the United States (Hill and Wang, New York)

Wired, 2000, "Rem Koolhaas: building the unmaterial world", http://www.aether.com/archives/ rem_koolhaas.html

Yaneva A, 2005, "Scaling up and down: extraction trials in architectural design" Social Studies of Science 35867 - 894

Yaneva A, 2009a Made by the Office for Metropolitan Architecture: An Ethnography of Design (010 Publishers, Rotterdam)

Yaneva A, 2009b The Making of a Building: A Pragmatist Approach to Architecture (Peter Lang, Oxford)

Žižek S, 1989 The Sublime Object of Ideology (Verso, London)

Zukin S, 1988, "The postmodern debate over urban form" Theory Culture Society 5431 - 446

Zukin S, 1991 Landscapes of Power: From Detroit to Disney World (University of California Press, Berkeley, CA)

Zukin S, 1995 The Cultures of Cities (Blackwell, Oxford) 
Conditions of use. This article may be downloaded from the E\&P website for personal research by members of subscribing organisations. This PDF may not be placed on any website (or other online distribution system) without permission of the publisher. 